\title{
PERSEPSI MASYARAKAT PESISIR TERHADAP PENGGUNAAN ENERGI ALTERNATIF UNTUK MELAUT.
}

\author{
Mira' $^{1}$ dan Riza Zulkarnen²
}

\begin{abstract}
ABSTRAK
Tujuan dari tulisan ini difokuskan untuk mengkaji persepsi masyarakat pesisir (nelayan) terhadap penggunaan energi alternatif untuk melaut, selain itu juga akan dianalisis faktor-faktor yang mempengaruhi nelayan untuk mengganti solar dengan biodiesel dalam mengatasi kelangkaan BBM. Lokasi penelitian yang dipilih adalah Cilacap dan penelitian dilakukan pada tahun 2006. Dari hasil pengolahan data, sebesar 72,50 persen nelayan mempunyai persepsi yang tinggi (positif) terhadap keberadaan biodiesel sebagai energi alternatif dalam mengatasi kelangkaan BBM. Persepsi nelayan yang rendah (negatif) akan menghambat pelaksanaan program desa nelayan mandiri energi, sedangkan persepsi yang tinggi (positif) merupakan dukungan dalam mencapai tujuan program desa nelayan mandiri energi. Terdapat $27,50 \%$ nelayan yang masih ragu-ragu tentang keberadaan biodiesel. Menurut nelayan keberadaan biodiesel belum tentu harganya lebih murah dibanding solar. Ada juga responden yang meragukan kualitas biodisel. Ada tiga faktor yang sangat mempengarugi responden dalam proses keputusan pembelian biodiesel harga, kualitas (keamanan), dan distribusi. Pada uji signifikansi 0,05 hasil analisis Spearman memperlihatkan adanya hubungan yang sangat tinggi (derajat asosiasi tinggi) antara harga dengan keputusan membeli biodisel, yaitu sebesar 1 (nilai koefisien korelasi), artinya semakin murah harga biodisel maka semakin besar keinginan responden untuk mengganti solar dengan biodiesel. Faktor distribusi menunjukkan adanya korelasi yang rendah, yaitu sebesar $-0,293$ pada uji signifikansi 0,05 .
\end{abstract}

Kata Kunci: Persepsi, Biodiesel.

\section{Abstract: Coastal Community Perception to Use Alternative Energi for Fishing. By: Mira and Riza Zulkarnen.}

This paper was focused on analyzing the coastal community perception on the use of alternative energy for fishing, as well as the factors influencing the fisher to substitute diesel fuel by biodiesel to overcome the high cost problem of fossil fuel. Research was conducted in Cilacap in 2006. The results showed that $72,50 \%$ of fishers indicated a high perception (positive) to biodiesel as alternative energy while $27,50 \%$ of fisher were uncertained to the use of biodiesel. According to fishers biodesel price was not lower then the solar price. Some fishers were also doubted to the quality of biodesel. There were 3 factors affecting responden to decide on the use of biodiesel : price, quality and distribution. The decision was highly affected by the price (coefficient value=1) based on Spearman analysis. It means, the cheaper the price, the more probability of respondents to use the biodiesel will be. Distribution factor shows a low correlation with value of $=-0,293$ at level significancy of 0.05 .

Key Words: Perception, Biodiesel.

\section{PENDAHULUAN}

Sejak kenaikan harga bahan bakar minyak (BBM) pada 1 Oktober 2005, banyak kapal penangkap ikan tidak dapat melaut. Setelah kenaikan harga BBM sekitar 500 kapal penangkap ikan tuna berbobot 100 gross ton
(GT) ke atas hanya ditambat di Pelabuhan Perikanan Muara Baru, Jakarta (Kompas, 2005). Harga BBM yang awalnya Rp. 2.200 per liter mengalami kenaikan menjadi Rp 6.200 per liter untuk industri dan Rp. 4.300 per liter untuk harga yang diterima nelayan. Oleh

\footnotetext{
1 Peneliti pada Balai Besar Riset Sosial Ekonomi Kelautan dan Perikanan

JI. KS. Tubun, Petamburan VI Slipi Jakarta.

2 Peneliti pada Pusat Riset Teknologi Kelautan

Jl. Pasir Putih ancol Jakarta Utara.
} 
karena itu beban operasional perusahaan semakin meningkat seiring dengan kenaikan harga bahan bakar minyak tersebut.

Pemakaian bahan bakar fosil ini pun semakin hari semakin meningkat sedangkan cadangan bahan bakar fosil dunia kian menipis. Kelangkaan bahan bakar minyak yang disebabkan oleh kenaikan harga minyak dunia yang signifikan, telah mendorong pemerintah Indonesia untuk mengajak masyarakat mengatasi masalah energi bersama-sama. Keadaan inilah yang kemudian memaksa masyarakat untuk kembali ke bahan bakar yang berasal dari alam maupun tumbuhan (bahan yang terbarukan).

Biodiesel merupakan bahan bakar dari minyak nabati yang memiliki sifat menyerupai minyak diesel/solar. Minyak jarak dipilih karena biodiesel yang dihasikan memiliki kualitas yang lebih tinggi dibandingkan biodiesel dari minyak nabati lain (Zulkarnain, 2006). Tanaman jarak mudah tumbuh dalam berbagai kondisi lahan, hal ini memudahkan regenerasi tumbuhan tersebut sehingga keberlanjutan penyediaan biodiesel dari biji jarak lebih terjamin. Adapun kelebihan biodiesel dibanding minyak diesel/solar diantaranya adalah merupakan bahan bakar yang ramah lingkungan karena menghasilkan emisi yang jauh lebih baik (bebas sulfur, jumlah asap rendah), bersifat non-toksik dan non-karsinogenik, dan memiliki sifat pelumasan terhadap piston mesin (Anonim, 2006).

Guna mengurangi ketergantungan nelayan terhadap solar yang harganya meningkat terus, maka diperlukan sumber energi alternatif mengatasi kelangkaan BBM. Penanaman dan usaha produksi biodiesel di desa nelayan selain akan meningkatkan produktifitas perikanan para nelayan malalui harga bahan bakar melaut yang lebih murah, juga akan memberikan peluang-peluang kegiatan ekonomi lain kepada masyarakat nelayan, seperti: peningkatan harga tanah untuk digunakan usaha penanaman tanaman jarak, usaha penjualan jarak, penyerapan tenaga kerja oleh perkebunan jarak dan proses produksi minyak biodiesel dan akibat ekonomi dari penurunan harga bahan bakar biodiesel untuk kapal ikan.

Hal-hal tersebut merupakan multiplier effect kegiatan ekonomi pemanfaatan biodiesel dari tanaman jarak yang akan berdampak pada pergerakan ekonomi sektor riil di masyarakat nelayan menuju DESA NELAYAN MANDIRI ENERGI, artinya masyarakat pesisir menanam jarak dan memproduksi biodiesel secara mandiri untuk digunakan sebagai bahan bakar untuk melaut.

Guna mengetahui apakah faktor-faktor yang mempengaruhi masyarakat nelayan untuk mengganti solar dengan biodiesel maka tujuan penelitian adalah mengkaji persepsi masyarakat pesisir terhadap penggunaan energi alternatif untuk melaut dalam mengatasi kelangkaan BBM. Persepsi nelayan terhadap penggunaan energi alternatif dalam mengatasi kelangkaan BBM merupakan salah satu faktor yang mempengaruhi keberhasilan program pembangunan desa nelayan mandiri energi. Persepsi nelayan yang rendah (negatif) akan menghambat pelaksanaan program desa nelayan mandiri energi, sedangkan persepsi yang tinggi (positif) merupakan dukungan dalam mencapai tujuan program desa nelayan mandiri energi. Selain itu juga akan dianalisis faktor-faktor yang mempengaruhi konsumen (nelayan) untuk mengganti solar dengan biodiesel.

Tulisan ini menganalisis data hasil penelitian berupa persepsi masyarakat pesisir (Cilacap) terhadap penggunaan energi alternatif.

\section{METODOLOGI}

\section{Lokasi dan Waktu Penelitian}

Penelitian dilakukan di daerah yang akan dijadikan percontohan, seperti Cilacap, di lokasi dimana terdapat atau pernah terdapat suatu bentuk sistem pemanfaatan sumber energi alternatif. Penelitian dilakukan pada tahun 2006. 


\section{Jenis dan Sumber Data}

Jenis data yang diambil adalah data sekunder dan data primer. Data sekunder diperoleh dari dokumen, laporan, dan publikasi lainnya yang terkait dengan kebutuhan riset, seperti laporan tahunan kabupaten, laporan tahunan dinas kelautan dan perikanan, dan data hasil penelitian sebelumnya. Data primer diperoleh dari hasil wawancara dengan nelayan yang menggunakan solar untuk melaut, serta pihak pemerintahan daerah.

Responden yang dipilih untuk mengetahui persepsi masyarakat terhadap biodiesel adalah nelayan pemakai solar di Cilacap yang tergabung dalam Kelompok Nelayan yang bernama Sentolo Kawat. Kelompok Nelayan Sentolo Kawat memiliki anggota sebanyak 2.598 orang, dimana semuanya memiliki kapal ukuran < 30 GT (Anonim, 2004), sangat cocok untuk konsumen pengguna biodiesel, yaitu untuk kapal-kapal yang memakai solar bersubsidi atau pemilik kapal-kapal kecil. Responden dipilih sebanyak 35 orang yang mewakili nelayan pemakai solar di Cilacap. Responden diklasifikasikan berdasarkan umur dan ukuran kapal. Yang digunakan proporsi terbesar responden ada pada ukuran kapal < $10 \mathrm{GT}$ yaitu sebanyak 20 orang atau sekitar 57 persen. Hal ini dikarenakan pemilik kapal ukuran < 10 GT mendominasi populasi dari responden.

Adapun hal yang ditanyakan adalah mengenai kelangkaan BBM, pengetahuan mereka terhadap sumber energi alternatif seperti biodiesel, faktor-faktor yang mempengaruhi dalam keputusan memilih biodiesel dibanding BBM. Faktor-faktor inilah yang menjadi variabel persepsi masyarakat terhadap penggunaan biodiesel sebagai sumber energi alternatif, yaitu:

1. Harga (apakah harga biodiesel lebih murah/mahal dibanding harga solar)

2. Distribusi (apakah biodiesel lebih mudah/sulit didapat dibanding solar)

3. Kualitas/keamanan (apakah penggunaan biodiesel lebih aman/tidak terhadap mesin kapal dibanding solar).

Data tentang variabel persepsi dikelompokkan berdasarkan jawaban yang sama. Mereka memilih biodiesel karena harga biodiesel lebih murah dibanding solar, selain itu juga karena pertimbangan keamanan (tidak merusak mesin kapal), dan faktor mudah didapat dimana saja. Pernyataan tersebut kemudian masing-masing diseleksi. Analisis Data di lakukan dengan menggunakan program SPSS level 13 untuk menguji korelasi spearman (Santoso, 2000). Persepsi masyarakat dikatakan tinggi apabila masyarakat setuju terhadap penggunaan energi alternatif sebagai pengganti BBM. Sedangkan persepsi masyarakat rendah apabila masyarakat tidak setuju terhadap penggunaan energi alternatif sebagai pengganti BBM.

\section{Metode Analisis Data}

Proses psikologis diasosiasikan dengan interpretasi dan pemberian makna terhadap orang atau objek yang tertentu yang dikenal sebagai persepsi. Persepsi adalah interpretasi terhadap berbagai sensasi sebagai representasi dari objek-objek eksternal (Salomon, 1996). Persepsi merupakan tanggapan atau pendapat dan penilaian responden tentang biodiesel. Persepsi adalah sebagai interpretasi terhadap berbagai sensasi sebagai representasi dari objek-objek eksternal (Hastuti, 2004). Jadi persepsi adalah pengetahuan tentang apa yang dapat ditangkap oleh indera kita (Bodaken, 1986). Perbedaan karakteristik individu dan pengaruh lingkungan akan mempengaruhi pembentukan persepsi responden, produsen lingkungan perbedaan individu.

Masyarakat yang memiliki persepsi positif apabila mereka mempunyai pengetahuan terhadap kegiatan tersebut (Rogers, 1988). Persepsi pada individu terhadap suatu gejala objek, dan rangsangan dapat positif, negatif, salah, benar, dan dapat berubah (Syahyuti, 
1998). Kejadian ini disebabkan oleh perbedaan yang dimiliki secara individual, bersifat pribadi dan unik. Perbedaan persepsi terhadap suatu objek yang sama dari individu yang berbeda, akan tetapi pada individu yang sama dapat juga berbeda persepsi dalam waktu yang berbeda. Menurut Azwar (2000) persepsi merupakan salah satu unsur sikap yang berupa respon evaluatif terhadap suatu gejala.

Salah satu hasil penelitian mengenai persepsi dilakukan oleh Susiatik (1998), yang menyatakan bahwa, persepsi masyarakat terhadapkegiatan pembangunan masyarakat. Desa hutan terpadu (PMDHT) di Mojorebo Kecamatan Wirosari, Grobogan, Jawa Tengah. Menyimpulkan bahwatingkat persepsi petani peserta PMDHT tersebut positif (tinggi) terhadap pelaksanaan kegiatan PMDHT. Tahapan-tahapan proses persepsi seperti pada gambar 1 (Salamon, 1996).
Terkait dengan data, menurut Manurung (2005) harus dikelompokan berdasarkan jawaban yang sama. Persepsi nelayan terhadap penggunaan energi alternatif dalam mengatasi kelangkaan BBM merupakan salah satu faktor yang mempengaruhi keberhasilan program pembangunan desa nelayan mandiri energi . Hal ini berarti masyarakat pesisir menanam jarak dan memproduksi biodiesel secara mandiri untuk digunakan sebagai bahan bakar untuk melaut. Persepsi nelayan yang rendah (negatif) akan menghambat pelaksanaan program desa nelayan mandiri energi, sedangkan persepsi yang tinggi (positif) merupakan dukungan dalam mencapai tujuan program desa nelayan mandiri energi. Mereka memilih biodiesel karena harga biodiesel lebih murah dibading solar, selain itu juga karena pertimbangan keamanan (tidak merusak mesin kapal), dan faktor mudah didapat dimana saja, kemudian pernyataan ini diskorsing.

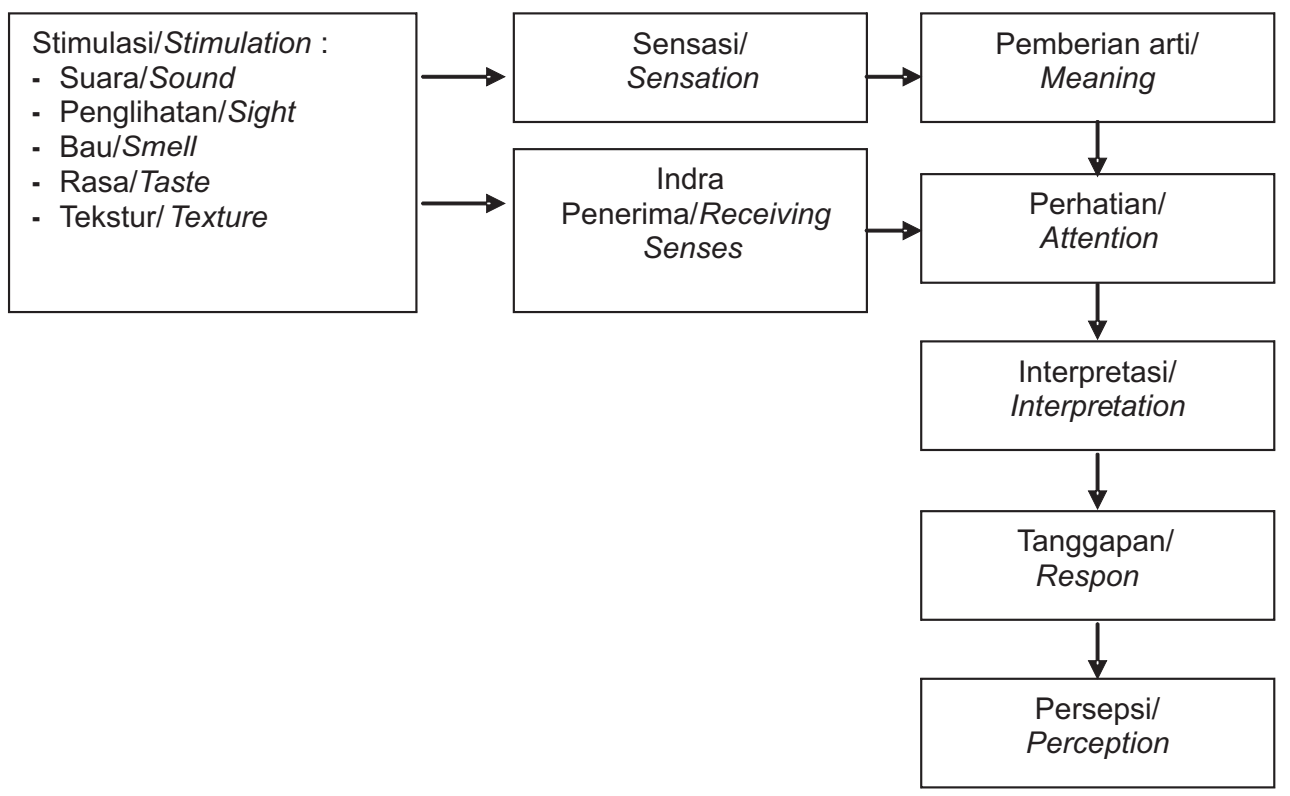

Gambar 1.Proses Persepsi Suatu Produk Terhadap Konsumen.

Figure 1. Perception Process of a Product by Consumers. 


\section{HASIL DAN PEMBAHASAN}

\section{Gambaran Umum Responden}

Responden yang dipilih untuk mengetahui persepsi masyarakat terhadap biodiesel adalah nelayan pemakai solar di Cilacap yang tergabung dalam Kelompok Nelayan "Sentolo Kawat". Kelompok nelayan ini sendiri menjadi anggota Koperasi Unit Desa (KUD) yang bernama KUD MinoSeroyo. Kedudukan ketua kelompok nelayan ini sangat kuat di mata anggotanya. Adapun penyelenggaraan kegiatan penyuluhan perikanan dilakukan dalam upaya pembinaan kelompok - kelompok nelayan. Kelompok nelayan sudah terkoodinir dalam satu wadah ekonomi yaitu KUD. Menurut hasil wawancara dengan kepala dinas perikanan, pembinaan kelompok, terutama sosialisasi biodiesel dilakukan secara terpadu baik dari Dinas Kelautan dan Perikanan, Himpunan Nelayan Seluruh Indonesia (HNSI), KUD, Dinas Pemerintahan yang terkait dengan peningkatan kesejahteraan nelayan.
Kelompok Nelayan Sentolo Kawat memiliki anggota sebanyak 2.598 orang, dimana semuanya memiliki kapal ukuran $<30$ GT (Anonim, 2004) sangat cocok untuk konsumen pengguna biodiesel, yaitu untuk kapal-kapal yang memakai solar bersubsidi atau pemilik kapal-kapal kecil. Adapun ukuran kapal mereka ada yang berukuran 29 GT, 28 GT, dan $15 \mathrm{GT}$, < $10 \mathrm{GT}$. Delapan puluh persen anggota dari Kelompok Nelayan Sentolo Kawat memiliki kapal yang berukuran < 10 GT. Kapal tersebut melakukan penangkapan di Pantai Selatan Samudera Indonesia, mulai dari perbatasan Jawa Tengah dan Jawa Barat (Pangandaran) sampai dengan perbatasan Jawa Tengah dan Jawa Timur (Pacitan).

Karakteristik responden yang diklasifikasikanberdasarkan umur dan ukuran kapal di gambarkan pada tabel 1

Responden sebagian besar umur 45 tahun - 54 tahun yang dikategorikan pada umur dewasa yaitu sebanyak 15 orang atau sekitar 43 persen. Jumlah terbanyak kedua ada pada kisaran umur 35 - 44 tahun

\section{Tabel 1. Karakteristik Umum Responden.}

Table 1. General Characteristic of Respondent.

\begin{tabular}{lrc}
\hline \multirow{2}{*}{ Karaktersitik/Characteristics } & \multicolumn{2}{c}{ Responden /Respondent } \\
\cline { 2 - 3 } & $\begin{array}{c}\text { Orang/number of } \\
\text { person }\end{array}$ & Persentase /Percentage (\%) \\
\hline 1.Umur/Age (year/tahun) & 5 & 14,29 \\
$25-34$ & 13 & 37,14 \\
$35-44$ & 15 & 42,86 \\
$45-54$ & 2 & 5,71 \\
$>55$ & 35 & 100 \\
\hline Total & & \\
\hline 2. Ukuran Kapal/Size of Boats & 20 & 57,14 \\
(GT) & 8 & 22,86 \\
$<10$ & 5 & 14,29 \\
11 s/d 15 & 2 & 5,71 \\
$16-25$ & $\mathbf{3 5}$ & $\mathbf{1 0 0}$ \\
$25-30$ & 200 & \\
\hline Total & 2 & \\
\hline
\end{tabular}

Sumber/Source: Data diolah, 2006/data processed, 2006. 
sebanyak 13 orang atau sebesar 37 persen. Jumlah responden yang berumur $>55$ paling sedikit yaitu hanya 2 orang atau sekitar 5 persen.

Proporsi terbesar responden ada pada ukuran kapal < 10 GT yaitu sebanyak 20 orang atau sekitar 57 persen. Hal ini dikarenakan pemilik kapal ukuran < 10 GT mendominasi populasi dari responden. Proporsi terbanyak kedua adalah pemilik kapal berukuran 11- 15 GT sebanyak 8 orang atau sekitar 23 persen. Sedangkan proporsi yang paling kecil adalah responden yang merupakan pemilik kapal ukuran 25 - 30 GT sebanyak 2 orang atau sekitar 6 persen.

Pendapatan responden berkisar antara Rp 600.000 - Rp 2.500.000, adapun keberagaman pendapatan responden ini ternyata disebabkan oleh oleh adanya perbedaan antara status $\mathrm{ABK}$ dan pemilik kapal disamping nelayan melaut dan tidak melaut. Demikian juga hasil sampingan diluar usaha penangkapan ikan dan adapula nelayan yang tidak mempunyai hasil sampingan. Namun umumnya responden tidak mempunyai hasil sampingan dan pendapatan rumah tangga bertumpu pada kepala keluarga. Berkaitan dengan pendapat ini.

\section{Persepsi Masyarakat Pesisir Terhadap Penggunaan Energi Alternatif Dalam Mengatasi Kelangkaan BBM}

Responden mengetahui informasi tentang biodisel dari media TV, teman, dan saat peresmian pabrik pengolah biodisel di Cilacap oleh Menteri Kelautan dan Perikanan (tabel 2). Sebanyak 22 orang atau 63 persen responden mengetahui biodiesel dari dari TV, sedangkan 20 persennya ( 7 orang) mengetahui biodiesel saat peresmian pabrik pengolah biodiesel oleh Menteri Kelautan dan Perikanan, dan 17 persen mengetahui biodiesel dari temannya (6 orang). Pada umumnya responden mengetahui informasi tentang biodesel yang diperoleh dari media televisi yang saat ini merupakan sarana yang paling cepat untuk menyampaikan informasi. Peranan tenaga penyuluh sebagai penyampai informasi tentang biodesel hampir tidak ada, karena hampir seluruh responden menjawab tidak ada peranan penyuluh Berdasarkan konfirmasi dari pihak Dinas Kelautan dan Perikanan, keberadaan tenaga penyuluh dirasakan masih sangat kurang baik kualitas maupun kuantitasnya. Kurangnya informasi dari penyuluh tidak hanya dirasakan tentang keberadaan biodiesel, tetapi tentang permasalahan teknis (baik budidaya ataupun penangkapan), hal ini dikeluhkan oleh semua responden dan pihak KUD, serta kelompok nelayan.

Dari hasil pengolahan data diketahui bahwa sebesar 72,50 persen nelayan mempunyai persepsi yang tinggi (positif) terhadap keberadaan biodiesel sebagai energi alternatif dalam mengatasi kelangkaan BBM. Artinya mereka dapat menerima keberadaan biodisel, karena dapat memberikan manfaat terutama dalam hal mengatasi kelangkaan BBM. Responden yang diwawancarai mengharapkan dengan adanya biodiesel ini dapat dijadikan sumber energi alternatif yang harganya lebih murah dibandingkan solar . Dari hasil perhitungan analisa usaha, harga BEP (break event point) biodiesel adalah Rp 4.065, tidak jauh berbeda dengan harga solar

Tabel 2. Sumber Pengetahuan Responden Tentang Biodiesel.

Table 2. Source of Respondent Knowledge on Biodiesel.

\begin{tabular}{lccc}
\hline Responden IRespondent & TVITV & Teman/ Coleague & $\begin{array}{l}\text { Saat Peresmian / } \\
\text { Ceremonial Events }\end{array}$ \\
\hline Jumlah & 22 & 6 & 7 \\
Persentase & 63 & 17 & 20 \\
\hline
\end{tabular}

Sumber/Source: Data diolah, 2006/Data processed, 2006. 
subsidi (Rp 4.300). Harga BEP biodiesel yang tidak jauh berbeda dengan harga solar, disebabkan karena langkanya bahan baku biodiesel (biji jarak) (Anonim, 2006). Sebanyak 27,50 nelayan yang masih raguragu tentang keberadaan biodiesel, karena menganggap harga biodiesel belum tentu lebih murah dibanding harga solar atau meragukan kualitas biodiesel. Perbedaan pengertian pengetahuan dan pengalaman menyebabkan adanya perbedaan dalam sikap dan tanggapan serta penerimaan seseorang terhadap sesuatu atau persepsi seseorang terhadap sesuatu.

Faktor-Faktor Penentu Dalam Proses Pengambilan Keputusan Penggunaaan Sumber Energi Alternatif Oleh Responden

Responden memberi penilaian terhadap faktor-faktor mereka memilih biodiesel. Mereka memilih biodiesel karena harga biodiesel lebih murah dibading solar, selain itu juga karena pertimbangan keamanan (tidak merusak mesin kapal), dan faktor mudah didapat dimana saja. Data diolah dengan SPSS level 13 untuk menguji korelasi spearman (Santoso, 2000). Hasilnya keseluruhan responden sudah mengetahui biodiesel.

Ada tiga faktor yang sangat mempengaruhi responden dalam proses keputusan pembelian biodiesel (tabel3) atau faktor-faktor yang mempengaruhi responden untuk mengganti solar dengan dengan biodiesel yaitu harga, kualitas (keamanan), dan distribusi. Dari hasil analisis, responden akan mengganti solar dengan biodiesel asalkan harga biodiesel lebih murah dari harga solar. Rata-rata konsumen di negara berkembang memang lebih sensitif terhadap harga.

\section{Tabel 3. Nilai Korelasi Spearman.}

Table 3. Spearman Correlation Value.

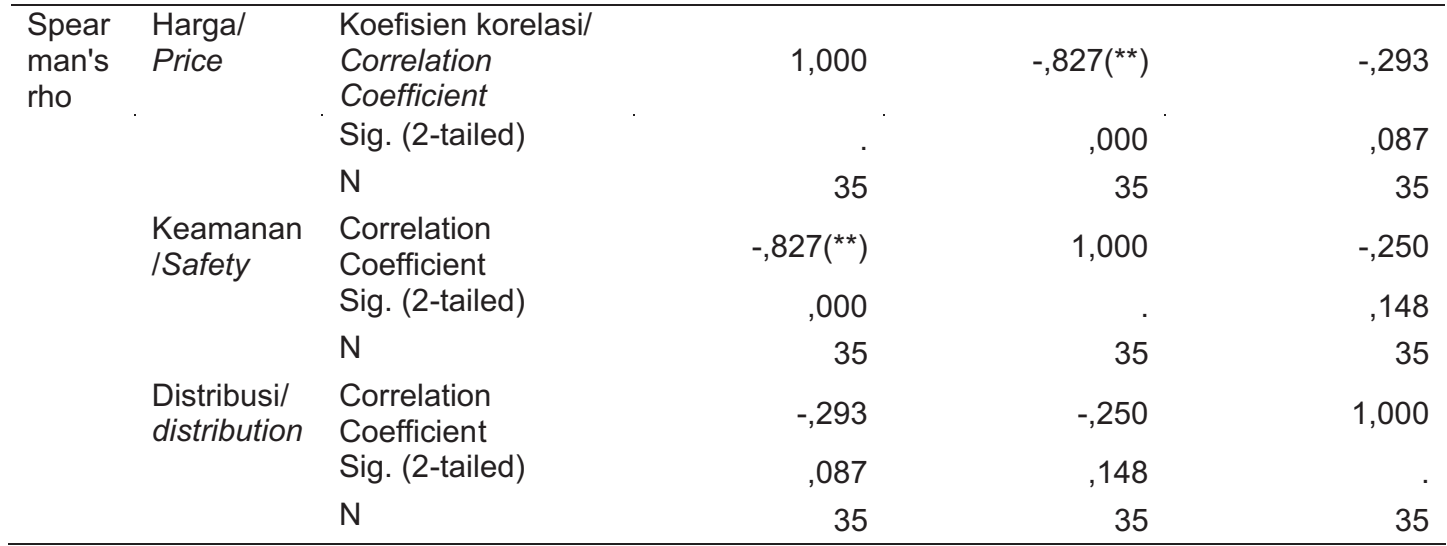

** Korelasi signifikan pada tingkat 0,01/Correlation is significant at the 0.01 level (2-tailed).

Tabel 4. Faktor-Faktor Yang Berpengaruh Dalam Pembelian Biodiesel.

Table 4.Factors Affecting on Purchasing Biodiesel.

\begin{tabular}{crc}
\hline Harga/Price & $\begin{array}{c}\text { Keamanan (kualitas) /Safety } \\
\text { (quality) }\end{array}$ & Distribusi \\
\hline 25 & 8 & 2 \\
8 & 25 & 2 \\
2 & 2 & 31 \\
\hline
\end{tabular}

Sumber/source:Data diolah, 2006/ Data processed, 2006. 
Tabel 5. Hubungan Faktor Yang Mempengaruhi Keputusan Responden Mengganti Solar Dengan Biodiesel.

Table 5. Relationship Factors Affecting the Respondents Decission to Substitute Diesel Fuel with Biodiesel.

\begin{tabular}{|c|c|c|c|}
\hline $\begin{array}{l}\text { Faktor - Faktor/ } \\
\text { Factors }\end{array}$ & $\begin{array}{c}\text { Taraf Nyata/ } \\
\text { Level of }\end{array}$ & $\begin{array}{l}\text { Nilai Koefisien } \\
\text { Korelasi /Coeficient } \\
\text { of correlation }\end{array}$ & $\begin{array}{l}\text { Kesimpulan / } \\
\text { Conclusion }\end{array}$ \\
\hline Harga/price & 0,05 & 1 & $\begin{array}{l}\text { Hubungan } \\
\text { Signifikan/Significant } \\
\text { relationship }\end{array}$ \\
\hline $\begin{array}{l}\text { Keamanan } \\
\text { (Kualitas)/Safety } \\
\text { (quality) }\end{array}$ & 0,01 & $-0,827$ & $\begin{array}{l}\text { Hubungan } \\
\text { Signifikan/Significant } \\
\text { relationship }\end{array}$ \\
\hline Distribusi/distribution & 0,05 & $-0,293$ & $\begin{array}{l}\text { Tidak terdapat } \\
\text { hubungan/no } \\
\text { correlation }\end{array}$ \\
\hline
\end{tabular}

Sumber/source:Data diolah, 2006/Data processed, 2006.

Pada uji signifikansi 0,05 hasil analisis Spearman memperlihatkan adanya hubungan yang sangat tinggi (derajat asosiasi tinggi) antara harga dengan keputusan membeli biodisel, yaitu sebesar 1 (nilai koefisien korelasi), artinya semakin murah harga biodisel maka semakin besar keinginan responden untuk membelinya.

Dari hasil analisis terhadap faktor yang mempengaruhi keputusan responden mengganti solar dengan biodesel diketahui bahwa, untuk faktor kualitas nilai korelasinya hanya sebesar -0, 827 pada uji signifikansi 0,01 . Artinya faktor kualitas menunjukan adanya hubungan yang subtansial dengan keputusan membeli biodiesel, meski nilainya lebih kecil ketimbang faktor harga. Sedangkan untuk faktor distribusi menunjukkan adanya korelasi yang rendah yaitu sebesar -0, 293 pada uji signifikansi 0,05, seperti yang tertera pada tabel 5 .

\section{KESIMPULAN DAN IMPLIKASI KEBIJAKAN}

\section{Kesimpulan}

1. Persepsi masyrakat terhadap keberadaan biodesel sangat tinggi $(72,50 \%)$ sedangkan $27,50 \%$ nelayan masih ragu-ragu.
2. Ada 3 faktor yang memepengaruhi persepsi dalam proses keputusan pembelian biodesel yaitu : Harga, Kualitas dan Disribusi.

3. Terdapat hubungan yang sangat tinggi (derajat asosiasi tinggi) antara harga dengan keputusan membeli biodesel.

\section{Implikasi Kebijakan}

Untuk membangun desa nelayan mandiri energi diharapkan mempertimbangkan faktor harga dan kualitas biodesel.

\section{DAFTAR PUSTAKA}

Anonim, 2004. Laporan Tahunan Dinas Kelautan dan Perikanan Cilacap. Dinas Kelautan dan Perikanan Cilacap.

Azwar, M. 2000. Persepsi Siswa Terhadap Sinentron Pernikahan Dini. Pasca Sarjana IPB. Bogor.

Bodaken, E.1986.Transfer Understanding Human Communication. Prestine Hall, Inc. New Jersey.

Hastuti, E. 2004. Aksebilitas Masyarakat Terhadap Kelembagaan Pembiayaan Pertanian di Pedesaan. Icaserd Working Paper, No.57. Pusat Penelitian Pengembangan Ekonomi Pertanian (PSE). Bogor. 
Kompas, 2005. Usaha Penangkapan Tuna Terancam Bangkrut. Kompas. Jakarta

Manurung, J.J.2005. Ekonomtrika Teori dan Aplikasi. Elex Media Komputindo. Jakarta Rogers, C. 1988. Adoslescent and Youth. Prestine Hall, Inc. New Jersey.

Salomon, M.R. 1996. Consumer Behaviour. Pretince Hall International.

Santoso, S. 2000. Buku Latihan SPSS Statistik Parametrik. Elex Media Komputindo.

Syahyuti. 1998. Analisis Pendekatan Penyuluhan Pembentukan Persepsi Petani Kasus Introduksi Teknologi SUTPA di Jawa Timur. Pusat Penelitian Pengembangan Ekonomi Pertanian (PSE). Bogor.
Susiatik, T. 1998. Persepsi Masyarakat Terhadap Kegiatan Pembangunan Masyarakat Desa Hutan Terpadu (PMHDT) di Grobogan, Jawa Tengah. Pasca Sarjana IPB. Bogor.

Zulkairnain, R. 2006. Laporan Teknis Kajian Pemanfaatan Energi Alternatif Oleh Masyarakat Pesisir. Pusat Riset Teknologi Kelautan. 